\title{
COMPARATIVE STUDY REGARDING THE PHYSICO-CHEMICAL PROPERTIES AND MICROBIOLOGICAL ACTIVITIES OF OLEA EUROPAEA L. OIL AND CANNABIS SATIVA L. SEED OIL OBTAINED BY COLD PRESSING
}

\author{
HANADI AL JOURDI ${ }^{1}$, CARMEN POPESCU ${ }^{2}$, DENISA IOANA UDEANU ${ }^{1 *}$, ANDREEA \\ ARSENE $^{1}$, ANI SEVASTRE ${ }^{3}$, BRUNO ȘTEFAN VELESCU $^{1}$, DUMITRU LUPULIASA ${ }^{1}$ \\ ${ }^{I}$ Faculty of Pharmacy, University of Medicine and Pharmacy "Carol Davila” Bucharest, Romania \\ ${ }^{2}$ S.C. Hofigal Export Import S.A., Romania \\ ${ }^{3}$ Craiova University of Medicine and Pharmacy, Romania \\ *corresponding author: denisaudeanu@gmail.com
}

\begin{abstract}
Herbal cosmetics are defined as products that have been prepared or included in plants and/or herbal components, which are combinations of many molecules or natural compounds. In this context, the critical parameters that affect the final quality and stability of herbal cosmetic products are the active principles, the formulation and the manufacturing process. Plant-based products used in cosmetics include vegetal oils and other lipids, essential oils used as perfumes or for their antimicrobial activities, skin and hair care ingredients, and antioxidants. The multiplicity of sources of cosmetic ingredients for plants presents many different ethical and scientific aspects that have not been previously considered or underestimated, such as resource regeneration, biodiversity conservation, improved isolation and extraction techniques, safety assessment of new raw materials and the development of innovative formulations. The study presents the physico-chemical characterization (organoleptic characteristics, refractive index, relative density, acidity index, peroxide index, fatty acids content) and microbiological evaluation of the fatty oils of vegetable origin obtained by cold pressing of Cannabis sativa L. seeds, as well as from the fruits of Olea europaea L.
\end{abstract}

\section{Rezumat}

Produsele cosmetice pe bază de plante sunt definite ca produsele care au fost preparate sau incluse plante și/sau componente din plante, care sunt combinații ale multor molecule sau compuși naturali. În acest context, parametrii critici care afectează calitatea finală şi stabilitatea produselor cosmetice pe bază de plante sunt principiile active, formularea şi procesul de fabricație. Produsele de origine vegetală utilizate în produsele cosmetice includ uleiuri vegetale și alte lipide, uleiuri esențiale folosite ca parfumuri sau pentru activităţile lor antimicrobiene, ingrediente pentru îngrijirea pielii şi părului şi antioxidanţi. Diversitatea surselor de ingrediente cosmetice pentru plante prezintă numeroase aspecte etice și științifice diferite care nu au fost considerate sau au fost subestimate anterior, cum ar fi regenerarea resurselor, conservarea biodiversitătii, tehnici de izolare şi extracție îmbunătățite, evaluarea siguranței noilor materii prime și, în cele din urmă, dezvoltarea de formulări inovatoare. Studiul prezintă caracterizarea fizico-chimică (caracteristicile organoleptice, indicele de refracție, densitatea relativă, indicele de aciditate, indicele de peroxid, conținutul în acizi grași) şi microbiologică a uleiurilor grase de origine vegetală obţinute prin presare la rece din semințe de Cannabis sativa L, precum și din fructele speciei Olea europaea L..

Keywords: Cannabis sativa seed oil, olive oil, fatty acids, physico-chemical characterization, skin care

\section{Introduction}

Cannabis sativa L. and Olea europaea L. have a long history of medicinal use and nutritional value since ancient times. Vegetal extracts, especially cold pressing oils obtained from these plants have been use for cosmetical purposes by many civilizations over time since ancient Egypt and China [1, 6, 11]. Nowadays, the most valuable cosmetic products incorporate vegetal products with preserved chemical composition close to the original plant $[2,13]$. The cold pressing technique is a reliable method for obtaining high quality products with complex chemical composition.

The proportion of the chemical constituents in fatty oil extracts are dependent on several environmental factors like soil composition, weather or collection time and also by plant genetics.

The cold press oils extracted from olives and hemps (Cannabis sativa L.) seeds contain a variety of ingredients which may act as functional ingredients in cosmetic formulations $[8,9,14]$. Thus, the chemical composition of these extracts has a high impact on the stability, hydration properties, oil holding capacity, 
viscosity or organoleptic characteristics of the final formulation [3, 5, 12, 15]

The article aims to analyse the physico-chemical properties including the fatty acids composition and the microbiological activities of the cold press oils extracted from Cannabis sativa L. seeds and Olea europaea L. fruits in order to characterize them for obtaining future optimized cosmetic formulations.

\section{Materials and Methods}

Vegetal oil samples

Six commercially available fatty oil samples obtained by cold pressure technique obtained from Cannabis sativa $\mathrm{L}$. seeds (C1, C2, C3), harvested in ecological crops from Romania, and respectively from Olea europaea L. fruits harvested in Spain (O1, O2, O3). Physico-chemical characterisation of the cold pressed fatty oils

The organoleptic characteristics, the relative density, the refractive index, the acidity index, the peroxide value and the main fatty acids (oleic, linoleic, palmitic, stearic acids) were assessed according to the European Pharmacopoeia $9^{\text {th }}$ Ed recommendations $[4,7]$.

Relative density $\left(\mathrm{d}_{20}{ }^{20}\right)$

The relative density $\left(\mathrm{d}_{20}{ }^{20}\right)$ was evaluated by the method provided by the European Pharmacopoeia $9^{\text {th }}$ Ed and was calculated as the ratio between the weights of the pycnometer filled with water and respectively with fatty oil, at $20^{\circ} \mathrm{C}[4,7]$.

Refractive index

The refractive index was measured in accordance with the European Pharmacopoeia $9^{\text {th }}$ Ed recommendations using a digital Kern ORF 85BM refractometer. The analyses were performed at $\lambda=589.3 \mathrm{~nm}$ at a temperature $20 \pm 0.5^{\circ} \mathrm{C}[4,7]$.

Acidity index

Reagents: ethylic alcohol $(96 \%, \mathrm{v} / \mathrm{v})$, diethyl ether, light petroleum ether R3, potassium hydroxide, phenolphthalein were of analytical grade (Sigma Aldrich). The used method complies with the European Pharmacopoeia $9^{\text {th }}$ Ed recommendations and briefly consist in the titration of a $5.0 \mathrm{~g}$ sample of fatty oil (diluted with an equal part mixture of ethylic alcohol and neutralized light petroleum ether) with $0.1 \mathrm{M}$ potassium hydroxide in the presence of phenolphthalein as indicator $[4,7]$.

Peroxide index

Reagents (Sigma Aldrich): chloroform, acetic acid, potassium iodide, mercuric iodide, sodium thiosulfate, starch were of analytical grade (Sigma Aldrich). The used method complies with the European Pharmacopoeia $9^{\text {th }}$ Ed recommendations and briefly consist in the titration of a $5.0 \mathrm{~g}$ sample of fatty oil (dissolved in chloroform and acetic acid) with $0.01 \mathrm{M}$ sodium thiosulphate in the presence of a starch as indicator. A control sample was analysed respecting the same procedure and conditions $[4,7]$.

\section{The fatty acids content}

Gas chromatographic analyses of the chemical compounds were implied, according to the Eur. Ph. $9^{\text {th }}$ Ed. [4, 7]. Reagents suitable for gas chromatography were purchased from Sigma Aldrich: petroleum ether, hydrochloric acid in methanol, isooctane, heptane, anhydrous sodium sulphate.

Equipment

Gas chromatograph with mass spectrometer detector (GC-MS tip Focus GP-DSQ-2, Finnigan ThermoScientific), split injection, automatic system for peak area integration with a macrogol 20000 GC column $(1=30 \mathrm{~m} ; \varnothing=0.25 \mathrm{~mm})$.

Chromatographic conditions: temperature program: $160^{\circ} \mathrm{C}$ (time $0-5 \mathrm{~min}$ ), the temperature was increased with $10^{\circ} \mathrm{C} / \mathrm{min}$ to $200^{\circ} \mathrm{C}$ (time $6-10 \mathrm{~min}$ ), and then increased to $225^{\circ} \mathrm{C}$ and maintained constant for $10 \mathrm{~min}$; injection port temperature: $220^{\circ} \mathrm{C}$; detector temperature $270^{\circ} \mathrm{C}$; split ratio: $1 / 60$; carrier gas: helium, at a flow rate of $1.5 \mathrm{~mL} / \mathrm{min}$; sample injected volume $1 \mu \mathrm{L}$ for each solution [7].

Standard solution: the standard calibration solution was prepared according to the Eur. Ph. $9^{\text {th }}$ Ed using heptane solvent. The chemical composition of the standard solution was the following: methyl laureate, methyl myristate, methyl palmitate, methyl stearate, methyl arachidate and methyl oleate.

Samples preparation

The fatty oil samples $(0.1 \mathrm{~g})$ were dissolved in petroleum ether and hydrochloric acid in methanol and was maintained at $65^{\circ} \mathrm{C}$ for $1 \mathrm{~h}$ under reflux. The sample was cooled and washed several times with water. Isooctane was added and the isooctane layer was separated and mixed with anhydrous sodium sulphate for water removal and then filtered.

\section{GS-MS method}

$1 \mu \mathrm{L}$ of standard solution and $1 \mu \mathrm{L}$ of fatty oil sample were injected in the GC/MS system and the retention times were determined. The minimum resolution determined by methyl oleate and methyl stearate in the standard solution chromatogram was minimum 1.8 between peaks. The seed fatty oil composition was identified based on MS spectrum library with $\mathrm{M} / \mathrm{Z}$ values: 40 - 450 . The normalizing procedure was applied in order to determine the percent concentration of the components [7].

Microbiology

Equipment: Venticell 111 oven, Incucell Incubator 404, Friocell Incubator 404, microbiological boxlaminar air flow Telstar AV 100 and BSC-EN I-IV.

Reagents, culture mediums and solutions used for (i) the determination of the total number of aerobic microorganisms (TAMCs): casein soya bean digest agar, buffered sodium chloride broth $\mathrm{pH}=7.0$; (ii) the determination of the total number of yeasts and filamentous fungi (TYMC): Sabouraud agar with dextrose, buffered sodium chloride broth $\mathrm{pH}=7.0$; (iii) the isolation and identification of gram-negative 
bacteria-tolerant bile salts: Enterobacteria enrichment broth (Mossel), violet red bile glucose agar, casein soya bean digest broth; (iv) the control of specific microorganisms, namely Escherichia coli and Salmonella sp.: MacConkey broth, MacConkey agar, casein soya bean digest broth, triple sugar iron agar (TSI), Rappaport Vassiliadis Salmonella enrichment broth, xylose, lysine, deoxycholate agar [4, 7].

\section{Results and Discussion}

Physico-chemical characterisation of the cold pressed fatty oils

Organoleptic characteristics, refractivity index and relative density

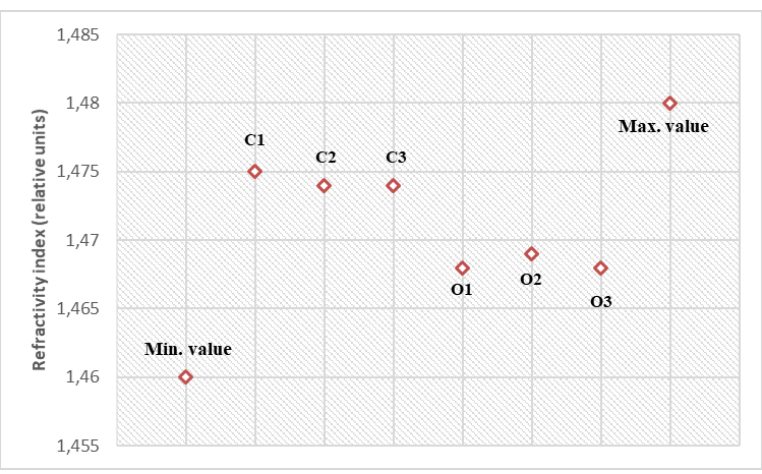

Figure 1.

Refractivity index of the analysed samples

\section{Acidity index}

The results for the acidity index from the analysed samples is presented in Table II.

Table I

Acidity index from the analysed samples

\begin{tabular}{|c|c|c|c|c|c|}
\hline \multicolumn{3}{|c|}{ Cannabis sativa L. oil } & \multicolumn{3}{c|}{ Olea europaea L. oil } \\
\hline C1 & C2 & C3 & O1 & O2 & O3 \\
\hline $0.75 \%$ & $0.50 \%$ & $0.60 \%$ & $0.65 \%$ & $0.60 \%$ & $0.55 \%$ \\
\hline \multicolumn{3}{|c|}{ Max: $6 \%$} & \multicolumn{3}{c|}{ Max: $0.80 \%$} \\
\hline
\end{tabular}

Regarding the acidity index, a parameter used to quantify the amount of fatty acids no longer linked to their parent triglyceride molecules, the Pharmacopoeia establishes a maximum value of $6 \%$ for Cannabis sativa L. oil and respectively $0.80 \%$ for Olea europaea L. oil. Our samples showed results which comply with the above mentioned limitations [4].

Peroxide index

The results for the peroxide index from the analysed samples is presented in Table I.

Regarding the acidity index, a parameter used to quantify the oil primary oxidation, the Pharmacopoeia establishes a maximum value of 10 for Cannabis sativa L. oil and respectively $20 \%$ for Olea europaea
The three samples of fatty oil obtained from Cannabis sativa L. seeds were opalescent oily liquids, yellowgreen colour with characteristic smell and bitter flavour. Regarding the refractivity index $(\mathrm{C} 1=1.475, \mathrm{C} 2=1.474$, $\mathrm{C} 3=1.474)$ (Figure 1$)$ and relative density $(\mathrm{C} 1=0.910$, $\mathrm{C} 2=0.911, \mathrm{C} 3=0.903$ ) (Figure 2) the samples were uniform and complied with the compendial requirements [4].

The results obtained for the three samples of fatty oil obtained from Olea europaea L. fruits were clearly oily liquids, golden-yellow colour with characteristic flavour and smell. Regarding the relative density, the samples were uniform $(\mathrm{O} 1=1.468, \mathrm{O} 2=1.469$, $\mathrm{O} 3=1.468)($ Figure 1$)$ and relative density $(\mathrm{O} 1=0.851$, $\mathrm{O} 2=0.860, \mathrm{O} 3=0.850$ ) (Figure 2 ) and complied with the compendial requirements [4].

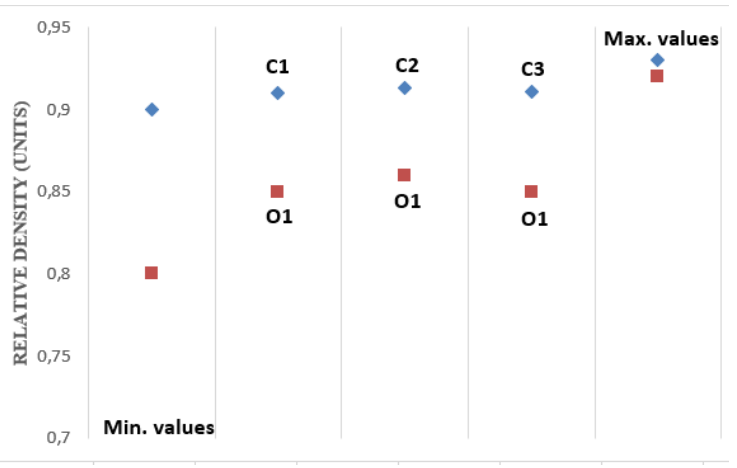

Figure 2.

Relative density of the analysed samples

L. oil. Our samples showed results which comply with the above mentioned limitations [4].

Table II

The peroxide index from the analysed samples

\begin{tabular}{|c|c|c|c|c|c|}
\hline \multicolumn{3}{|c|}{ Cannabis sativa L. oil } & \multicolumn{3}{c|}{ Olea europaea L. oil } \\
\hline C1 & C2 & C3 & O1 & O2 & O3 \\
\hline 1.20 & 0.60 & 0.90 & 2.31 & 3.20 & 2.76 \\
\hline \multicolumn{3}{|c|}{ Max: 10} & \multicolumn{3}{c|}{ Max: 20} \\
\hline
\end{tabular}

The fatty acids content

The chromatographic analyses of the olive oil revealed the presence of palmitic acid $(\sim 13 \%)$, linoleic acid $(12 \%)$ and oleic acid (67\%). The chromatographic analyses of the Cannabis sativa L. seeds oil revealed the presence of the following unsaturated fatty acids: oleic acid $(\sim 13 \%)$, stearic acid $(\sim 15.7 \%)$ and linolenic acid (16\%). In all samples, the omega 3,6 and 9 fatty acids concentration was $86 \%$, which is a higher level in comparison with the olive oil samples composition (Figure 3). In both cold press olive oil and hemp seeds oil, the level of the unsaturated fatty acids are in respect to the chemical composition mentioned by the scientific literature. $[3,10]$ 


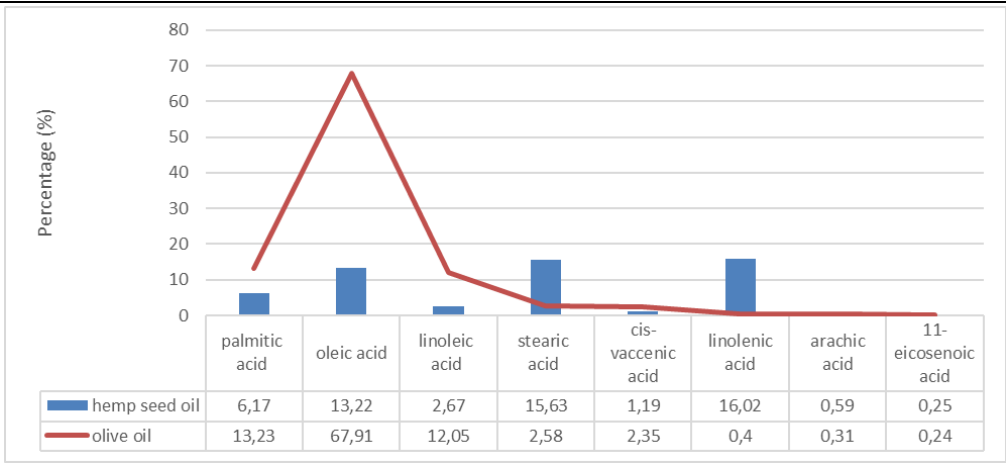

Figure 3.

Fatty acid composition of the analysed samples

The chemical composition analyses sustain the advantages of using these cold press oils in the composition of cosmetic formulation especially in case of skin hydration ointments due to a high level of linoleic acid in case of olive oil and a varied composition of omega 3, 6 and 9 fatty acid detected in case of hemp seed oil.

According to current regulations the olive oil has to be investigated for the presence of: palmitoleic acid (maximum content $3.5 \%$ ), behenic and lignoceric acids (both maximum content $0.20 \%$ ). Our samples showed a value of $0,65 \%$ palmitoleic acid and below $0.01 \%$ for both behenic and lignoceric acids.

The evaluation of the microbial contamination of the cold press oils extracted from Cannabis sativa $L$. seeds and Olea europaea L. fruits

The results obtained from the microbiological analysis of cold press oil samples of olive and hemps seeds are presented in Table III.

Table III

The results obtained from the microbiological assays of fatty oil samples of Canabis sativa L. seed oil and Olea europaea L. fruits samples

\begin{tabular}{|l|c|c|c|}
\hline \multicolumn{1}{|c|}{ Microbial contamination assays } & Limits & $\begin{array}{c}\text { Canabis sativa } \mathrm{L} . \\
\text { seed oil samples }\end{array}$ & $\begin{array}{c}\text { Olea europaea } \mathrm{L} . \\
\text { fruits oil samples }\end{array}$ \\
\hline Total aerobic microorganisms (TAMC), CFU/mL, max. & $1 \times 10^{4}$ & $<10$ & $<10$ \\
Combined total yeast and filamentous fungi (TYMC), CFU/mL, max. & $1 \times 10^{2}$ & $<10$ & $<10$ \\
Gram-negative bile salts tolerant bacteria, CFU/mL, max. & $1 \times 10^{2}$ & $<10$ & $<10$ \\
Escherichia coli/mL & absent & absent & absent \\
Salmonella spp./25 mL & absent & absent & absent \\
\hline
\end{tabular}

Also, the samples were tested for the presence of Escherichia coli and Salmonella spp., according to the official rules in force. Our results showed the absence of the mentioned strains, for all the studied fatty oil samples.

The microbiological analyses demonstrated that there was no microbial contamination developed during the technological process (cold pressing) of natural fatty oil preparations, for all the oil samples studied in respect to the European Pharmacopeia recommendations regarding the quality of the natural products of vegetal origin [4].

The aim of the study was the physico-chemical and microbiological evaluation of two natural oils, namely the essential oils of hemp seed and olive, with the aim of further formulating safe and efficient cosmetic preparations $[1,2]$.

The main active constituents of the plant species studied and used in the formulation of cosmetic products are biocompatible fatty acids (unsaturated fatty acids), which contribute to the restoration of the skin protective lipid film, vegetal oils containing vitamins, minerals and essential fatty acids, which provide nutrition and optimal skin hydration and at the same time, it is a barrier for topical protection against inappropriate environmental conditions $[6$, $11,12]$.

Hemp seed oil (Cannabis sativa L. seed oil) is the richest oil in polyunsaturated fatty acids (optimum ratio of 3:1 between Omega 3 and Omega 6), known for their emollient and moisturizing properties. They contribute to keeping the water in the epidermis, maintaining it hydrated, supple and healthy. It has anti-inflammatory, antibacterial properties, accelerating healing of skin wounds, regenerating skin and hair [11].

Cold pressed olive oil is also called "liquid gold" because of its beneficial properties for the body. Cold pressed olive oil contains mainly monounsaturated fatty acids (omega-9). When polyunsaturated fatty acids are missing from a product, omega- 9 fatty acids can take over their role, thus restoring the balance of fatty substances. The benefits of olive oil are due to both the high content of both monounsaturated fatty acids and antioxidant substances $[9,12,13]$. 
FARMACIA, 2019, Vol. 67, 5

The results of our study sustain the use of both natural oils for dermatocosmetic purposes. Similar data were also reported in the literature, although differences may arise due to the different geographical areas the plant was cultivated [15].

\section{Conclusions}

Natural oils have been used in skin care for ancient times, rapidly spreading around the world from Egypt and Greece. Still, they resided over the years and even more, there is a continuous focus on adding new use for their benefits, scientifically documented. They are available from easy reachable natural bioresources and also cost-effective compared to other, synthetic, alternatives. The most important aspect when considering a natural oil for skin care is it's composition, because each one possesses an unique profile of active ingredients, namely a particular content in essential fatty acids. That is why the association between oils of different bioresources is usually preferred when formulating a dermatocosmetic product, assuring in this way a more complex benefit on the skin. In this regard, our study revealed that the association between Cannabis sativa L. seed oil and Olea europaea L. oil may offer an attractive profile of fatty acids combination for skin care use. Further researches will be employed for developing safe and efficient dermatocosmetic formulations using both natural oils.

\section{Acknowledgement}

This paper was financially supported by "Carol Davila" University of Medicine and Pharmacy through Contract no. CNFIS-FDI-2019-0534 (MEDEX-II) funded by the Ministry of National Education of Romania, from the Institutional Development Fund for Public Universities - FDI 2019.

\section{References}

1. Aburjai T, Natsheh FM, Plants used in cosmetics. Phytotherapy Research: An International Journal Devoted to Pharmacological and Toxicological Evaluation of Natural Product Derivatives, 2003; 17(9): 987-1000.

2. Barbulova A, Colucci G, Apone F, New trends in cosmetics: By-products of plant origin and their potential use as cosmetic active ingredients. Cosmetics, 2015; 2(2): 82-92.
3. Da Porto C, Decorti D, Tubaro F, Fatty acid composition and oxidation stability of hemp (Cannabis sativa L.) seed oil extracted by supercritical carbon dioxide. Industrial Crops and Products, 2012; 36(1): 401-404.

4. European Pharmacopoeia, 9.0 Edition, 2016, Council of Europe, Strasbourg, France

5. Georgescu M, Tăpăloagă PR, Tăpăloagă D, Furnaris F, Ginghină O, Negrei C, Giuglea C, Bălălău C, Ștefănescu E, Popescu IA, Georgescu D, Evaluation of antimicrobial potential of Nigella sativa oil in a model food matrix. Farmacia, 2018; 66(6): 10281036.

6. Ghanbari R, Anwar F, Alkharfy KM, Gilani AH, Saari N, Valuable nutrients and functional bioactives in different parts of olive (Olea europaea L.) - A review. Int J Molec Sci., 2012; 13(3): 3291-3340.

7. Khalass S, Popescu C, Popescu IA, Arsene AL, Udeanu DI, Lupuliasa D, Physico-chemical and microbiological characterization of Fagopyrum esculentum Moench. fatty oil obtained by cold pressure. Farmacia, 2018; 66(5): 899-903.

8. Kowalska M, Ziomek M, Żbikowska A, Stability of cosmetic emulsion containing different amount of hemp oil. Int J Cosmetic Sci., 2015; 37(4): 408416.

9. Mikulcová V, Kašpárková V, Humpolíček $P$, Buňková L, Formulation, characterization and properties of hemp seed oil and its emulsions. Molecules, 2017; 22(5): 1-13.

10. Oomah BD, Busson M, Godfrey DV, Drover JC, Characteristics of hemp (Cannabis sativa L.) seed oil. Food Chem., 2002; 76(1): 33-43.

11. Ranalli P, Venturi G, Hemp as a raw material for industrial applications. Euphytica, 2004; 140(1-2): 1-6.

12. Rodrigues F, Pimentel FB, Oliveira MBP, Olive by-products: Challenge application in cosmetic industry. Industrial Crops and Products, 2015; 70: 116-124.

13. Smaoui S, Hlima HB, Jarraya R, Kamoun NG, Ellouze R, Damak M, Cosmetic emulsion from virgin olive oil: Formulation and bio-physical evaluation. Afr J Biotech., 2012; 11(40): 96649671.

14. Tabassum N, Hamdani M, Plants used to treat skin diseases. Pharmacognosy Rev., 2014; 8(15): 52-62.

15. Vogl CR, Mölleken H, Lissek-Wolf G, Surböck A, Kobert J, Hemp (Cannabis sativa L.) as a resource for green cosmetics: Yield of seed and fatty acid compositions of 20 varieties under the growing conditions of organic farming in Austria. $J$ Ind Hemp, 2004; 9(1): 51-68. 